\title{
PEMANFAATAN MICROSOFT POWERPOINT SEBAGAI SOLUSI STRATEGI VISUAL DIGITAL MARKETING UNTUK UMKM DI MASA PANDEMI
}

\author{
Alvian Alrasid Ajibulloh'1) \\ 1)Program Studi Ilmu Komunikasi, Fakultas Ekonomi dan Sosial, Universitas Amikom Yogyakarta, Yogyakarta, Jawa Tengah, \\ Indonesia \\ Corresponding author: Alvian Alrasid Ajibulloh \\ E-mail : alvianaa@amikom.ac.id
}

Diterima 24 September 2020, Direvisi 08 Oktobet 2020, Disetujui 10 Oktober 2020

\begin{abstract}
ABSTRAK
Wabah Coronavirus Diseases 2019 (Covid-19) telah membuat Indonesia kerepotan, mengharuskan Pemerintah Indonesia memberlakukan aturan Pembatasan Sosial Berskala Besar (PSBB) dan penerapan social distancing dan juga work from home. Akibatnya, banyak perubahan perilaku yang dilakukan oleh masyarakat terutama pada daya beli dan konsumsi. Ini memberikan dampak besar terhadap keberlangsungan sektor UMKM. Menurut kajian yang dibuat oleh Kementerian Keuangan Republik Indonesia menunjukkan bahwa pandemi COVID-19 memberikan implikasi negatif bagi perekonomian domestik seperti penurunan konsumsi dan daya beli masyarakat, penurunan kinerja perusahaan, ancaman pada sektor perbankan dan keuangan, serta eksistensi UMKM. Kondisi seperti ini membuat beberapa intansi; LPM Universitas Amikom Yogyakarta, Talenta Muda Indonesia dan Smartfren Community, menginisiasi suatu kegiatan sosial yang bertujuan membantu pelaku UMKM melalui segi pengetahuan. Kegiatan ini dilakukan dengan metode daring, melalui media platform Zoom meeting dan disiarkan secara langsung melalui Youtube channel milik Smartfren community. Kegiatan ini dibuka untuk umum terkhusus untuk para pelaku UMKM. Peserta tidak hanya mendapatkan materi tapi juga mendapatkan template desain konten promosi, yang mana template ini bisa diubah sesuai dengan keinginan atau kebutuhan UMKM. Tujuan pelatihan ini ingin memberikan insight atau wawasan baru bagi para pelaku UMKM, yang mana kegiatan ini bisa menjadi satu inspirasi untuk bisa survive and struggle disituasi pandemi ini.
\end{abstract}

Kata kunci: pemasaran digital; desain visual; microsoft powerpoint.

\begin{abstract}
The 2019 Coronavirus Diseases (Covid-19) outbreak has made Indonesia inconvenient, requiring the Indonesian Government to impose large-scale social restrictions (PSBB) and implement social distancing and also work from home. As a result, many changes in behavior have been made by the community, especially in terms of purchasing power and consumption. This has a big impact on the sustainability of the UMKM sector. According to a study made by the Ministry of Finance of the Republic of Indonesia, it shows that the COVID-19 pandemic has negative implications for the domestic economy, such as a decrease in public consumption and purchasing power, a decline in company performance, threats to the banking and financial sectors, and the existence of UMKM. Conditions like this create several institutions; LPM Yogyakarta Amikom University, Indonesian Young Talenta and Smartfren Community, initiated a social activity that aims to help UMKM players through a knowledge perspective. This activity is carried out using the online method, through the Zoom meeting media platform and broadcast live via the Smartfren community's Youtube channel. This activity is open to the public, especially for UMKM players. Participants not only get material but also get promotional content design templates, which can be changed according to the wishes or needs of UMKM. The purpose of this training is to provide new insights or insights for UMKM players, which this activity can be an inspiration to be able to survive and struggle in this pandemic situation.
\end{abstract}

Keywords: digital marketing; visual design; microsoft powerpoint.

\section{PENDAHULUAN}

Di tahun 2020, Indonesia menghadapi

Wabah Coronavirus Diseases 2019 (Covid-19). Indonesia sudah dibuat kerepotan olehnya, berbagai sektor kehidupan manusia terkena dampaknya. Tentu fakta tersebut membuat resah masyarakat, sehingga mengharuskan Pemerintah Indonesia memberlakukan aturan Pembatasan Sosial Berskala Besar (PSBB) dan penerapan pyshical or social distancing dan 
juga work from home (Hadi, S., 2020). Himbauan tersebut pada prinsipnya sangat efektif mencegah penularan Coronavirus. Namun bagi beberapa orang dianggap "mimpi buruk", terutama bagi para pelaku usaha UMKM. Ketidakpastian kerja menjadi sumber kekhawatiran terbesar bagi pekerja selain takut tertular atau menularkan Covid-19 (Siswanto, 2020).

Kajian yang dibuat oleh Kementerian Keuangan Republik Indonesia menunjukkan bahwa pandemi COVID-19 memberikan implikasi negatif bagi perekonomian domestik seperti penurunan konsumsi dan daya beli masyarakat, penurunan kinerja perusahaan, ancaman pada sektor perbankan dan keuangan, serta eksistensi UMKM (Kementerian Keuangan Republik Indonesia, 2020). Menurut data Rilis Badan Pusat Statistik (BPS) tentang pertumbuhan ekonomi triwulan II-2020, terjadi penurunan ekonomi nasional menjadi $-5,32 \%$ (Badan Pusat Statistik, 2020). Dan menurut Menteri Koperasi dan UMKM Teten Masduki berdasarkan hasil survei yang dilakukan sejumlah lembaga dan Kementerian Koperasi dan UKM (Kemenkop UKM), wabah COVID-19 memberikan dampak besar terhadap keberlangsungan UMKM. Sebanyak 1.785 koperasi dan 163.713 pelaku usaha mikro kecil menengah terdampak pandemi virus Corona, (Rani Ummi Fadila, 2020).

Untuk beradaptasi disituasi sulit ini implementasi strategi pemasaran yang tepat, memiliki pengetahuan yang baik dan absorptive capacity dapat menciptakan eksistensi bisnis usaha yang produktif dan meningkat kinerja bisnisnya (Fitriyani, 2020). Pelaku UMKM dan koperasi juga bisa memanfaatkan teknologi informasi dan komunikasi (TIK), mengingat menurut data bahwa perdagangan elektronik di tahun 2020 mencapai US\$ 130 miliar (Rani Ummi Fadila, 2020). Data ini memberikan angin segar bagi pelaku UMKM, mereka bisa mengoptimalkan kegiatan pemasarannya melalui online dan digital branding sebagai sarana komunikasi dengan target konsumennya, seperti melalui website yang dijadikan e-commerce, social media, search engine, penjualan melalui marketplace, dan membentuk tim reseller untuk menjual produknya. Penggunaan media digital memberikan peluang untuk memperluas jangkauan pasar (Slamet, Nainggolan, \& Ramdani, 2016) dan menjadi media penting untuk berkomunikasi dengan pelanggan seperti pada masa COVID-19 yang interaksi dengan pelanggan menjadi terbatas.

Akan tetapi, dari peluang ini terdapat 2 (dua) permasalahan baru, yaitu (i) tidak semua pelaku UMKM paham akan transisi dan peluang ini, terutama cara membuat konten promosi digital yang menarik dan mudah. (ii) Sebagian dari mereka juga masih berpikir bahwa proses ini membutuhkan biaya yang cukup lumayan. Sehingga membuat mereka bimbang untuk memutuskan, karena disatu sisi mereka harus saving money agar ketika nanti semuanya kembali normal mereka bisa melanjutkan usahanya kembali, dan di sisi lain mereka juga harus bertahan dan berjuang agar usahanya tetap terus berjalan.

Situasi seperti ini membuat beberapa intansi terketuk hatinya. Seperti yang dilakukan oleh LPM Universitas Amikom Yogyakarta, Talenta Muda Indonesia dan Smartfren Community, ketiga instansi ini menginisiasi suatu kegiatan sosial atau pengabdian kepada masyarakat yang bertujuan membantu pelaku UMKM melalui segi pengetahuan. Pelatihan ini menitik beratkan pada bagaimana memanfaatkan Microsoft Powerpoint untuk membuat konten promosi yang menarik sebagai solusi strategi digital marketing. Microsoft Powerpoint adalah program aplikasi presentasi yang populer dan paling banyak digunakan saat ini untuk berbagai kepentingan presentasi baik pembelajaran, presentasi produk, meeting, seminar, likakarya dan sebagainya (Rudi., Cepi., 2009).

Tujuan pelatihan ini ingin memberikan insight atau wawasan baru bagi para pelaku UMKM, yang mana kegiatan ini bisa menjadi satu inspirasi untuk bisa survive and struggle disituasi pandemi ini.

\section{METODE}

Pelaksanaan kegiatan ini diadakan pada hari kamis, tanggal 06 Agustus 2020, secara daring dengan menggunakan platform Zoom meeting dan disiarkan secara langsung melalui Youtube channel milik Smartfren community. Kegiatan ini dibuka untuk umum terkhusus untuk para pelaku UMKM. Peserta tidak hanya mendapatkan materi pelatihan tapi juga mendapatkan template desain konten promosi secara gratis, yang mana template ini bisa diubah sesuai dengan keinginan atau kebutuhan UMKM.

Kegiatan ini memaparkan dua materi penting; (i) Materi pembuka yang menjelaskan tentang strategi pemasaran dan perubahan perilaku konsumen di masa pandemi. (ii) Materi inti yang mengajarkan bagaimana cara mengoperasikan Microsoft Powerpoint untuk keperluan membuat konten promosi dan apa saja tahapan-tahapannya.

Prosedur kegiatan program pengabdian masyarakat ini meliputi beberapa tahapan: 
1. Studi Pendahuluan.

Pada tahapan studi pendahuluan akan dilakukan kegiatan-kegiatan sebagai berikut: (a) Analisa persoalan pada situasi saat ini, apa yang dibutuhkan oleh para pelaku UMKM pada sisi pengetahuan atau keilmuan. (b) Melakukan penyusunan rencana kerja dan instrumen pelaksanaan program. (c) Penetapan tim pelaksana dan uraian kerjanya sesuai kepakaran yang dimiliki.

2. Pelaksanaan.

Pada tahapan pelaksanaan, akan dilakukan kegiatan-kegiatan sebagai berikut: (a) Promosi mengenai kegiatan dan pembukaan pendaftaran. (b) Para peserta diberikan link zoom. (c) Pemaparan materi secara daring dengan menggunakan platform zoom meeting dan live streaming youtube channel. (d) Pembagian materi dalam bentuk softcopy dan materi free template konten promosi dengan cara mengirim via e-mail.

3. Evaluasi.

Pada tahap evaluasi, peserta diminta kesediaan untuk memberikan feedback melalui google form. Hasil pada tahapan evaluasi akan dijadikan dasar dalam menyusun laporan pelaksanaan program pengabdian.

\section{HASIL DAN PEMBAHASAN}

Kegiatan ini memiliki tema; "3 cara mudah membuat konten promosi dengan powerpoint'. Dihadiri oleh 65 Peserta pada saat live zoom. Kegiatan ini juga disiarkan secara live di Youtube channel Smartfren community ; https://www.youtube.com/watch?v=vXqQXAC3 jbw\&t $=5301 \mathrm{~s}$.

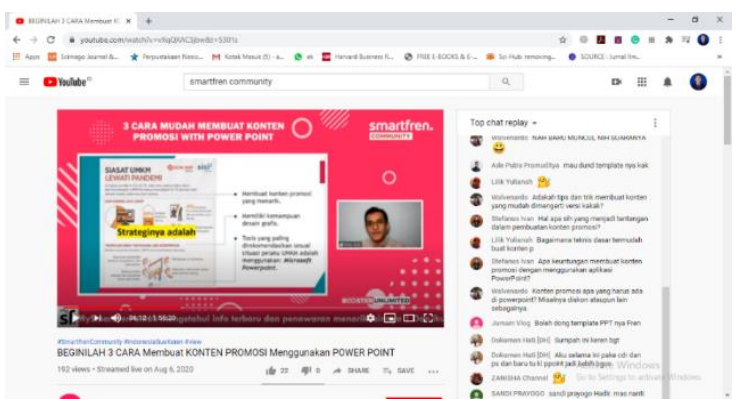

Gambar 1. Screenshot Live Streaming. (Sumber: Youtube channel Smartfren community)

Pada awal kegiatan pelatihan peserta diberikan materi pengantar tentang, kenapa Microsoft Powerpoint bisa dijadikan salah satu solusi strategi visual untuk UMKM pada masa pandemi. Yang dipaparkan oleh Alvian Alrasid
Ajibulloh, S.IKom., M.I.Kom perwakilan dari LPM Universitas Amikom Yogyakarta yang juga berprofesi sebagai dosen ilmu komunikasi. Materi ini bertujuan untuk memberikan wawasan baru kepada peserta, bahwa pada saat pandemi banyak perubahan perilaku yang dilakukan oleh konsumen, dampak dari penerapan aturan physical or social distancing.

Materi ini juga menjelaskan bahwa dimana setiap hambatan, dipastikan ada peluang atau celah bagi manusia yang dikarunai akal pikiran dan budi pekerti. Teknologi menjadi sarana untuk beradaptasi. Situasi ini dapat digunakan untuk menyampaikan pesan berbasis teknologi digital apapun bentuknya yang akan menghubungkan setiap individu dengan antar individu ataupu dengan komunitasnya. Dalam teknologi, diperlukan salah satu elemen penting, yaitu desain. Beragam desain mampu sebagai media untuk menyampaikan informasi yang menjadi perantara solusi atas kondisi saat ini (Primasiwi, 2020).

Materi ini juga menjelaskan kenapa harus menggunakan Microsoft Powerpoint, dan apa kelebihannya dibandingkan dengan software desain lainnya. Program Microsoft Powerpoint di dalam komputer dirancang khusus untuk menyampaikan presentasi, baik yang diselenggarakan oleh perusahaan, pemerintah, pendidikan, maupun perorangan, dengan berbagai fitur menu yang mampu menjadikan media ini menarik untuk digunakan sebagai alat presentasi, yaitu sebagai pengelolaan teks, warna, gambar, serta animasi-animasi yang bisa diolah sendiri sesuai dengan kreatifitas penggunaannya (Maryatun, 2015).

Dengan demikian untuk mengurangi dampak negatif pada sektor pelaku UMKM, mereka dituntut untuk mampu memahami perubahan-perubahan perilaku dan menemukan inovasi yang tepat dan cepat sesuai kebutuhan dengan tujuan agar strategi pemasaran yang dilakukan oleh para pelaku UMKM tercapai dan memastikan keberlanjutan usahanya di masa pandemi ini.

Setelah materi pengantar, materi selanjutnya yakni materi inti, peserta langsung belajar atau berlatih bagaimana cara membuat konten promosi yang menarik melalui media Microsoft Powerpoint dan apa saja tahapannya. Satu persatu dibahas secara interaktif oleh Bpk. Harlan Purwanto perwakilan dari Smartfren Community yang juga menjabat sebagai ketua pelaksana komunitas Smartfren se-Indonesia. Melalui pelatihan ini peserta mampu memahami cara kerja atau proses membuat konten promosi di Microsoft Powerpoint.

Setelah 7 hari video Live streaming di 
Youtube ditayangkan mulai dari 6 Agustus s/d 13 Agustus 2020, tim pengabdian masyarakat menganalisa video tersebut dengan menggunakan Youtube analytics. Dari sini kami menghasilkan beberapa hasil analisa yakni; Pertama, berdasarkan dari jangkauan selama 7 hari, video ini mengalami peningkatan mencapai 1,9 ribu tayangan.

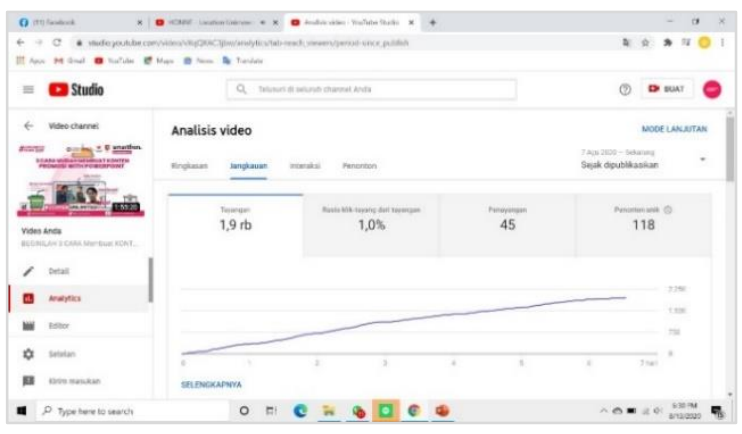

Gambar 2. Screenshot Hasil Analisa Berdasarkan Jangkauan. (Sumber: Youtube analytics dari channel Smartfren community)

Kedua, berdasarkan penonton selama 7 hari, video ini mendapatkan 118 penonton unik. Ketiga, berdasarkan subscriber, selama 7 hari di awal video ini telah menyumbangkan 2 subcriber baru. Artinya kegiatan ini memiliki respon yang sangat positif.

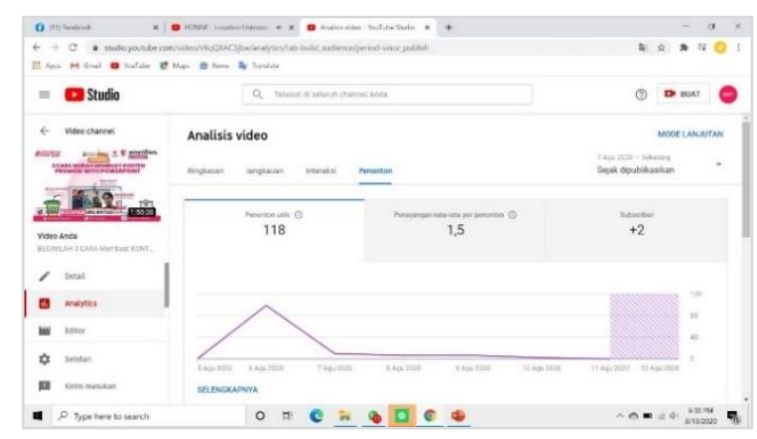

Gambar 3. Screenshot Hasil Analisa Berdasarkan Penonton dan Subcriber Baru. (Sumber: Youtube analytics dari channel Smartfren community)

Setelah kegiatan, para peserta juga diminta untuk memberikan feedback melalui google form, yang memberikan feedback hanya 19 peserta. Hasil dari tersebut dapat disimpulkan melalui gambar sebagai berikut. Dari pertanyaan pertama, apakah Anda ingin diadakan kegiatan webinar kembali dengan topik yang berbeda. 19 responses menjawab "iya" semua, (100\%).
Apakah Anda ingin diadakan kegiatan Webinar kembali dengan topik yang berbeda? 19 responses
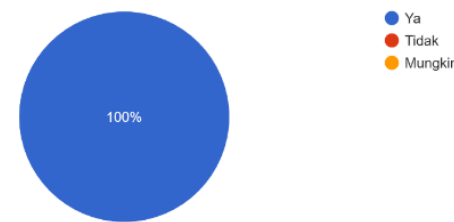

Gambar 4. Screenshot Hasil Analisa Quetioner Feedback Pertanyaan 1. (Sumber: Google Form Kegiatan Pengabdian Masyarakat)

Dari pertanyaan kedua, apakah Anda merasa puas dengan materi hari ini. Dari 19 responses memberikan 11 peserta menjawab sangat puas $(57,9 \%)$ dan 8 peserta menjawab puas $(42,1 \%)$.

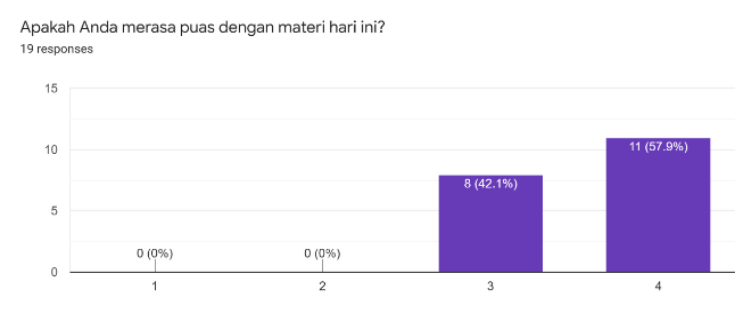

Gambar 5. Screenshot Hasil Analisa Quetioner Feedback Pertanyaan 2. (Sumber: Google Form Kegiatan Pengabdian Masyarakat)

Dari pertanyaan ketiga, apakah template design grafis yang kami berikan, sangat bermanfaat bagi Anda. Dari 19 responses memberikan 12 peserta menjawab sangat bermanfaat $(63,2 \%)$ dan 7 peserta menjawab bermanfaat $(36,8 \%)$.

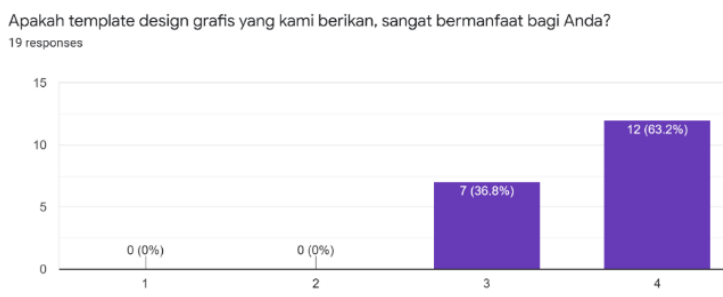

Gambar 6. Screenshot Hasil Analisa Quetioner Feedback Pertanyaan 2. (Sumber: Google Form Kegiatan Pengabdian Masyarakat)

\section{SIMPULAN}

Dalam membantu mengembangkan keberlanjutan UMKM pasca pandemi Covid-19, diperlukan optimisme pelaku usaha untuk bangkit, dan strategi yang matang, serta penguatan manajemen bisnis di bidang pemasaran, keuangan, sumber daya manusia dan bidang operasional. 
Dari kegiatan pengabdian masyarakat ini peserta mendapatkan wawasan baru dan mampu membuat desain konten promosi melalui Microsoft Powerpoint. Peserta juga merasa sangat terbantu, karena mendapatkan template gratis yang berisikan konten desain promosi, yang bisa digunakan sewaktu-waktu sesuai kebutuhan mereka.

\section{DAFTAR RUJUKAN}

Badan Pusat Statistik. (2020). Ekonomi Indonesia Triwulan II 2020 Turun 5,32 Persen. Retrieved from https://www.bps.go.id/website/materi_i nd/materiBrslnd-20200805114633.pdf

Fitriyani, I. (2020). Strategi Manajemen Bisnis Pasca Pandemi Covid-19. Indonesian Journal of Social Sciences and Humanities, 1(2), 87-95. https://doi.org/https://doi.org/10.15797/ concom.2019..23.009

Hadi, S., dan S. (2020). Revitalization Strategy for Small and Medium Enterprises after Corona Virus Disease Pandemic (Covid-19) in Yogyakarta. Xi'an Jianzhu Keji Daxue Xuebao/Journal of Xi'an University of Architecture \& Technolog, 12(4), $\quad$ 4068-4076. https://doi.org/https://www.researchgat e.net/deref/http\%3A\%2F\%2Fdx.doi.org \%2F10.37896\%2FJXAT12.04\%2F114 9

Kementerian Keuangan Republik Indonesia. (2020). Press Conference; Langkah Penguatan Perlindungan Sosial Dan Stimulus Ekonomi Menghadapi Dampak Covid-19. Retrieved from https://www.kemenkeu.go.id/media/14 790/materi-konferensi-pers-1-april2020.pdf

Maryatun. (2015). Pengaruh Penggunaan Media Program Microsoft Powerpoint Terhadap Hasil Belajar Strategi Promosi Pemasaran Mahasiswa Semester 2 Program Studi Pendidikan Ekonomi Universitas Muhammadiyah Metro Tahun Ajaran 2014/2015. Jurnal Promosi, 3(1), 1-13. Retrieved from https://media.neliti.com/media/publicati ons/162555-ID-none.pdf

Primasiwi, A. (2020). Peranan Desain dalam Pandemi Covid-19 Dibahas dalam Webinar Internasional. Retrieved from https://www.suaramerdeka.com/news/ nasional/230265-peranan-desaindalam-pandemi-covid-19-dibahasdalam-webinar-internasional

Rani Ummi Fadila. (2020). 1.785 Koperasi dan 163.713 UMKM Terdampak Pandemi Covid-19. Retrieved from https://www.pikiran-

rakyat.com/ekonomi/pr-

01379615/1785-koperasi-dan-163713umkm-terdampak-pandemi-covid-19

Rudi., Cepi. (2009). Media Pembelajaran. Bandung: CV Wacana Prima.

Siswanto. (2020). Krisis Covid-19, Pekerja Film Sampai Desainer Grafis Kehilangan Pendapatan. Retrieved from https://akurat.co/news/id-1084384read-krisis-covid19-pekerja-filmsampai-desainer-grafis-kehilanganpendapatan

Slamet, R., Nainggolan, B., \& Ramdani, H. (2016). Development Strategy Of Digital Start Up To. 136-147. 